\title{
CYR61/CCN1 stimulates proliferation and differentiation of osteoblasts in vitro and contributes to bone remodeling in vivo in myeloma bone disease
}

\author{
HUI LIU* , FENGPING PENG* , ZHAOYUN LIU* , FENGJUAN JIANG, LIJUAN LI, SHAN GAO, \\ GUOJIN WANG, JIA SONG, ERBAO RUAN, ZONGHONG SHAO and RONG FU \\ Department of Hematology, Tianjin Medical University General Hospital, Tianjin 300052, P.R. China
}

Received August 23, 2016; Accepted November 28, 2016

DOI: $10.3892 /$ ijo.2016.3815

\begin{abstract}
Cysteine-rich 61 (CYR61/CCN1), a secreted protein in bone marrow (BM) microenvironment, has diverse effects on many cellular activities such as growth and differentiation. However, the effect of CCN1 on osteoblasts (OBs) in myeloma bone disease remains unclear. In our study, the level of CCN1 in multiple myeloma (MM) patients was detected by ELISA and RT-PCR. The proliferation and differentiation of OBs from MM patients were observed after stimulated by CCN1 in vitro. The myeloma cells transduced with CYR61 gene (RPMI-8226/CYR61) were injected in a mouse model to evaluate the efficacy of CCN1 in vivo and compare with zoledronic acid. The results showed that CYR61/CCN1 levels in BM supernatant and OBs both elevated significantly in all newly diagnosed MM patients, especially in patients without bone disease $(\mathrm{P}=0.001$ and $\mathrm{P}<0.001)$. After $30 \mathrm{ng} / \mathrm{l} \mathrm{CCN} 1$ stimulation for $24 \mathrm{~h}$, the quantity and mineralization of $\mathrm{OBs}$ increased significantly in vitro $(\mathrm{P}=0.046$ and 0.048$)$. The transcription factors of Wnt pathway, runt-related transcription factor 2 (Runx2) and $\beta$-catenin were upregulated in OBs after $\mathrm{CCN} 1$ stimulation $(\mathrm{P}=0.012$ and 0.011$)$. After injection of RPMI-8226 cells, bone lesions were observed obviously by microCT and histochemistry at 7 weeks. Radiographic analysis of the bones showed decreased resorption in CCN1 overexpression group and zoledronic acid group, while severe resorption in negative control. Furthermore, trabecular bone volume in CCN1 overexpression group $(1.7539 \pm 0.16949)$ was significantly higher than zoledronic acid group $(1.2839 \pm 0.077)$ $(\mathrm{P}=0.012)$. In conclusion, $\mathrm{CCN} 1$ can stimulate the prolifera-
\end{abstract}

Correspondence to: Dr Rong Fu, Department of Hematology, Tianjin Medical University General Hospital, 154 Anshan Street, Heping District, Tianjin 300052, P.R. China

E-mail: florai@sina.com

${ }^{*}$ Contributed equally

Key words: myeloma bone disease, CCN1, osteoblasts, $\beta$-catenin, Runx2, bone remodeling tion and differentiation of OBs in vitro and contribute to bone remodeling in vivo in MBD.

\section{Introduction}

Multiple myeloma (MM) is a hematologic malignancy of terminally differentiated plasma cells. A most common complication of MM is myeloma bone disease (MBD), occurring in $>80 \%$ of $\mathrm{MM}$ patients. Bone lesions in $\mathrm{MM}$ are the result of imbalance between osteoclasts (OCs) and osteoblasts (OBs), the activation of OCs and inhibition of OBs $(1,2)$. Many studies have focused on the function of OCs and found RANKL/RANK system, which became the target of treatement $(3,4)$. However, osteolytic lesions still exist after the inhibition of OCs, which is associated with the inhibition of OBs. Recent research showed many cytokines in bone marrow (BM) microenvironment participate in the pathogenesis of MBD, such as CCL3 $(5,6)$, activin A (7), alpha hypoxiainducible factor (HIF-1 $\alpha)(8)$, pim-2 (9), cysteine-rich protein 61 (CYR61) (10), which may be new targets in MBD.

CYR61 is the first cloned member of the CCN family, an immediate early gene family consisting of six members, CTGF, NOV, WISP-1, WISP-2 and WISP-3 $(11,12)$. CYR61 is known to link cell surface and extracellular matrix and plays important roles on cell adhesion, proliferation, migration, differentiation and angiogenesis during normal developmental and pathophysiological processes (11). Clines et al (13) found that tumor-produced endothelin-1 increased osteoblasts proliferation and new bone formation by activating Wnt signaling pathway through suppression of Wnt pathway inhibitor DKK1 in murine primary OBs culture. Si et al (14) suggested that tightly regulated CCN1/CYR61 expression may play an important role in Wnt3A-induced OBs differentiation from mesenchymal stem cells. In MC3T3-E1 osteoblasts, CYR61 upregulated BMP-2, resulting in enhanced cell proliferation and osteoblastic differentiation through activation of the $\alpha(\mathrm{v}) \beta(3)$ integrin/integrin-linked kinase/ERK signaling pathway (15). The study of Chen et al (16) in osteoarthritis indicated that CCN1 heightened OSM expression via $\alpha(v) \beta(3)$ receptor, FAK, c-Src, PI3K, and NF- $\kappa \mathrm{B}$ pathway in osteoblastic cells. Johnson et al (10) found that recombinant CCN1 directly inhibited growth of MM cells in vitro, and overexpression of CYR61 in 
MM cells prevented bone destruction in vivo. However, still scarce research exists of CCN1 on OBs in MM patients. In our study, we cultured OBs from MBD patients with recombinant $\mathrm{CCN} 1$ and observed the effect of CCN1 on OBs in vitro, then further investigated the effect of $\mathrm{CCN} 1$ on bone remodeling in vivo.

\section{Patients and methods}

Study subjects. Thirty-six newly diagnosed MM patients (20 males and 16 females) were enrolled in this study. The participants were selected as inpatients in the Hematology Department of Tianjin Medical University General Hospital from January 2015 to November 2016 according to the International Myeloma Workgroup criteria. According to $\mathrm{X}$-ray scanning data obtained before treatment, bone disease was graded into three stages: stage A, no osteolytic lesions or osteoporosis alone; stage $\mathrm{B}$, one to three osteolytic lesions; stage $\mathrm{C}$, more than three osteolytic lesions and/or a pathological fracture (17). There were 9 patients in stage $A$ and 27 in stage $\mathrm{B} / \mathrm{C}$ in our study. The characteristics of the patients are shown in Table I. Eighteen healthy volunteers with a median age of 48 years (range, $42-69$ years) were included as normal controls. Bone marrow aspirations were collected from all the patients diagnosed with MM and from normal controls. This study was approved by the Ethics Committee of the Tianjin Medical University. Written informed consent was obtained from the patients for the publication of this report and any accompanying images.

Enzyme-linked immunosorbent assay. The CCN1 level in the bone marrow supernatant was assessed using the CCN1 ELISA kit (R\&D Systems, Inc., Minneapolis, MN, USA). Human paraprotein (Lambda) level in the mouse model was detected using the Human Lambda ELISA kit (Bethyl Laboratories, Inc., Montgomery, TX, USA). Diluted standards and patient serum $(100 \mu \mathrm{l})$ were added in duplicate and incubated at $37^{\circ} \mathrm{C}$ for $1 \mathrm{~h}$. After washing the plates 5 times, $100 \mu \mathrm{l}$ of antibody was added to each well and incubated at room temperature for $1 \mathrm{~h}$. Next, HRP was added to each well. After incubation at $37^{\circ} \mathrm{C}$ for $30 \mathrm{~min}$, the wells were washed 5 times. Then, TMB solution was added to each well, and the samples were incubated in the dark at room temperature for $20 \mathrm{~min}$. Finally, a stop solution was added, and the OD was read at $450 \mathrm{~nm}$ within $15 \mathrm{~min}$.

Cell culture. The bone marrow mononuclear cells (BMMNC) were separated using Ficoll-Hypaque density sedimentation. The BMMNCs were cultured in Dulbecco's modified Eagle's medium/F12 medium supplemented with $15 \%$ fetal bovine serum (Gibco, Darmstadt, Germany), $1 \times 10^{-7} \mathrm{~mol} / \mathrm{l}$ dexamethasone, $0.05 \mathrm{~g} / 1$ vitamin C, $0.01 \mathrm{~mol} / 1 \beta$-sodium glycerophosphate, $100 \mathrm{~g} / \mathrm{ml}$ penicillin (Gibco), and $100 \mathrm{U} / \mathrm{ml}$ streptomycin (Gibco). Non-adherent cells were removed the next day, and the media were replaced every other day. Adherent BMMNCs were cultured at $37^{\circ} \mathrm{C}$ in an atmosphere containing $5 \% \mathrm{CO}_{2}$. The OBs were counted and seeded in 24-well plates at a plating density of $1 \times 10^{4}$ cells $/ \mathrm{cm}^{2}$. Trypsin was used to detach three wells of OBs for cell count every second day. The number of cells was used to draw the OB growth curve. The OB doubling time (DT) was calculated using the following formula: $D T=$ $t \times[\lg 2 /(\lg N t-\lg N o)]$, where $t$ is the culturing period (h); No is the cell density when the cells were seeded; and $N t$ is the cell density when the cells were cultured after $t$ hours.

The OBs were divided into two groups: the blank group and CCN1 group (OBs were cultured with CCN1: 10 and $30 \mathrm{ng} / \mathrm{l}$ ). The changes in the OB osteogenic potential and biological characteristics were observed after intervention.

Quantitative real-time PCR. The total RNA from the OBs of each group was extracted using the TRIzol reagent (Invitrogen). The TIANScript RT kit (Tiangen, Beijing, China) was utilized to reverse-transcribe $1 \mu \mathrm{g}$ of RNA. Table II presented the primer sequences of runt-related transcription factor 2 (Runx2), $\beta$-catenin, CYR61, bone morphogenetic protein-2 (BMP2) and GAPDH. These primer sequences were designed and synthesized by Sangon Biotech (Shanghai, China).

The quantitative real-time PCR was performed using the Bio-Rad iQ 5 Real-time system (Bio-Rad, Hercules, CA, USA). The SYBR Green (Invitrogen) was used as a double-strand DNA-specific dye. The amplification of CYR61 and Runx2 utilized 40 cycles at $95^{\circ} \mathrm{C}$ for $30 \mathrm{sec}$ and $95^{\circ} \mathrm{C}$ for $5 \mathrm{sec}$ with the extension at $57^{\circ} \mathrm{C}$ for $30 \mathrm{sec}$. The amplification of BMP2 and $\beta$-catenin both utilized 45 cycles at $95^{\circ} \mathrm{C}$ for $30 \mathrm{sec}$ and $95^{\circ} \mathrm{C}$ for $5 \mathrm{sec}$ with the extension at $55^{\circ} \mathrm{C}$ for $30 \mathrm{sec}$. GAPDH was employed as the housekeeping gene to standardize the targeted mRNA expression. The CYR61, Runx2, $\beta$-catenin and BMP2 levels were calculated using the $2^{-\Delta \Delta C t}$ method $[(\mathrm{Ct}$, target gene $\left.\mathrm{Ct}, \mathrm{GAPDH})_{\text {sample }}-(\mathrm{Ct} \text {, target gene } \mathrm{Ct}, \mathrm{GAPDH})_{\text {control }}\right]$ after normalizing the data according to the GAPDH mRNA expression.

$A L P$ and Von Kossa staining. The alkaline phosphatase (ALP) expression was an early osteoblast marker detected using the ALP Staining kit (Sigma-Aldrich, Taufkirchen, Germany). The expression was utilized to confirm the presence of OB. Von Kossa staining was performed to confirm that the OB synthesized and mineralized the extracellular matrix. The mineralized nodules were found in both groups cultured for 3 weeks. The amount of mineralized nodules in each patient was counted and used as an indicator of $\mathrm{OB}$ function.

Lentiviral vector and myeloma cell transduction. The sequence of cDNA for human CYR61 (GENE-ID 3491) was cloned into the Ubi-MCS-SV40-EGFP-IRES-puromycin vector. Lentiviral particles were generated by cotransfecting the expression vector Ubi-MCS-SV40-EGFP-IRES-puromycin and ViraPower Packaging Mix into 293T cells according to the Invitrogen ViraPower Lentiviral Expression Systems protocol (18).

Myeloma cells (RPMI-8226) were plated at a density of $5 \times 10^{4}$ cells per well in a 6 -well plate. For each of the following 3 days, cells were exposed to viral supernatant at $1 \times 10^{8} \mathrm{TU} / \mathrm{ml}$ in the presence of polybrene $(5 \mu \mathrm{g} / \mathrm{ml})$. Transduced RPMI-8226/ CYR61 cells were used for experiments in vivo. The efficiency of transduction was determined using analysis of GFP expression. We detected the expression of CYR61/CCN1 by qRT-PCR, ELISA and western blotting. In addition, the proliferation of non-transduced RPMI-8226, transduced with CYR61 or EV RPMI-8226 cells was measured by CCK-8 kit. 
Table I. Profiles of patients with MM enrolled in this study.

\begin{tabular}{lc}
\hline Total no. of patients & 36 \\
Gender & $20 \mathrm{M}-16 \mathrm{~F}$ \\
Age-median (range) & $68(43-80)$ \\
Type of MM & IgG (17), IgM (7), IgA (5), \\
& $\begin{array}{c}\text { light-chain }(6), \\
\text { non-secretory }(1)\end{array}$ \\
Stage at diagnosis (ISS) & \\
I & $6(17 \%)$ \\
II & $8(22 \%)$ \\
III & $22(61 \%)$ \\
Bone disease & $9(25 \%)$ \\
Stage A & $27(75 \%)$ \\
Stage B/C & \\
Parameters at baseline & $18(50 \%)$ \\
Creatinine clearance $>30 \mathrm{ml} / \mathrm{min}$ & $18(50 \%)$ \\
Creatinine clearance $\leq 30 \mathrm{ml} / \mathrm{min}$ & $7(19 \%)$ \\
Hb $\geq 100 \mathrm{~g} / \mathrm{l}$ & $29(81 \%)$ \\
Hb $<100 \mathrm{~g} / 1$ & $7(19 \%)$ \\
Ca $>2.75 \mathrm{mmol} / 1$ & $29(81 \%)$ \\
Ca $\leq 2.75 \mathrm{mmol} / \mathrm{l}$ & \\
\hline
\end{tabular}

MM, multiple myeloma; Hb, hemoglobin; Ca, calcium.

Animal model of myeloma bone disease. Female NOD/SCIDcc null mice at 5 weeks of age (the Chinese Academy of Medical Sciences Institute of Radiation Medicine) were acclimatized to the animal housing facility for 1 week before experiments. All of the experimental procedures on animals were carried out with strict adherence to the rules and guidelines for the ethical use of animals in research.

Fifteen microliter of the cell suspension $\left(1 \times 10^{6}\right.$ cells per inoculum) were injected directly into the marrow space of right tibia. The needle was inserted 3-5 $\mathrm{mm}$ down the diaphysis of the tibia through the cortex of the anteria tuberosity. The left contralateral tibia was injected with PBS alone as an internal control (19). Ten mice were investigated for myeloma cell infiltration and bone disease at 3,5 and 7 weeks after transplantation, respectively.

In the next experiment, mice were randomized into three groups (bone disease group as a control, zoledronic acid group and CCN1 overexpression group) of 10 mice per group. For the control and zoledronic acid groups, RPMI-8226/EV myeloma cells were injected into the marrow space of right tibia. In parallel, RPMI-8226/CYR61 cells were injected to the mice of CCN1 overexpression group. From the fourth week after myeloma cell injection, mice of zoledronic acid group were injected subcutaneously with antiresorptive bisphosphonate zoledronic acid (Novartis Pharma) at $100 \mu \mathrm{g} / \mathrm{kg} /$ dose once weekly for 4 weeks. All the mice were sacrificed at 7 weeks after myeloma cell inplantation.

Analysis of bone disease (microCT). Tibiae were fixed in formalin and scanned using a microCT scanner (model 1172;
Table II. Primer sequences.

\begin{tabular}{lll}
\hline Target & \multicolumn{1}{c}{ Sense and antisense sequences } & bp \\
\hline Runx2 & F: 5'-GACGAGGCAAGAGTTTCACC-3' & 106 \\
& R: 5'-GGTTCCCGAGGTCCATCTAC-3' & \\
3-catenin & F: 5'-GCTTTGTGTCGTCTTGAACG-3' & 122 \\
& R: 5'-TCAGCAATCCCTTTCTCACC-3' & \\
CYR61 & F: 5'-GAAGCGGCTCCCTGTTTTTG-3' & 174 \\
& R:5'-CGGGTTTCTTTCACAAGGCG-3' & \\
BMP2 & F: 5'-TCAAGCCAAACACAAACAGC-3' & 103 \\
& R: 5'-AGCCACAATCCAGTCATTCC-3' & \\
GAPDH & F: 5'-GCACCGTCAAGGCTGAGAAC-3' & 100 \\
& R: 5'-TGGTGAAGACGCCAGTGGA-3' & \\
\hline
\end{tabular}

bp, base pairs.

Skyscan) at $50 \mathrm{kV}$ and $200 \mathrm{AA}$ with a pixel size of $4.3 \mathrm{Am}$, an image being captured every $0.7^{\circ}$ through $180^{\circ}$ rotation of each bone. During scanning, the samples were enclosed in a tightly fitting rigid plastic tube to prevent movement, scanned images were reconstructed and analyzed using the Skyscan Recon and Skyscan CT analysis software, respectively. The following three-dimensional (3D) parameters were measured: total bone volume/total volume, bone surface area/bone volume, trabecular thickness, trabecular number, trabecular spacing and trabecular bone volume (20).

Immunohistochemistry and histochemistry in the mouse model. Immunohistochemistry (IHC) staining was performed using formalin-fixed, complete decalcification was confirmed with 2 weeks of decalcification in $0.5 \mathrm{~mol} / 1 \mathrm{EDTA} / 0.5 \%$ paraformaldehyde in $\mathrm{PBS}(\mathrm{pH} 8.0)$ at $4^{\circ} \mathrm{C}$ and tibiae were then paraffin-embedded. Longitudinal sections $(5 \mu \mathrm{m})$ were prepared and stained with IHC. Anti-CD138 antibody (sc-69833 Santa Cruz Biotechnology, Santa Cruz, CA, USA; 1:200) was used. Tatrate-resistant acid phosphatase (TRAP) staining, a well-recognized marker of osteoclasts in vivo, was performed with an acid phosphatase kit (Sigma, St. Louis, MO, USA). Analysis was done on an Olympus CX41 microscope (21).

Statistical analysis. SPSS 16.0 (SPSS, Inc., Chicago, IL, USA) was used to perform the statistical analysis. The data are expressed as the mean $\pm \mathrm{SD}$ or median. The unpaired t-test and one-way ANOVA analysis were used to analyze the significance between different groups. Non-parametric test was used when the data were of abnormal distribution. A value of $\mathrm{P}<0.05$ was considered statistically significant.

\section{Results}

CYR61/CCN1 is elevated significantly in all newly diagnosed MM patients, especially in patients without bone disease (stage A). We detected CCN1 level in BM supernatant by ELISA in newly diagnosed patients and normal controls. The levels of $\mathrm{CCN} 1$ in the patients in stage $\mathrm{A}$ and stage $\mathrm{B} / \mathrm{C}$ were 
A

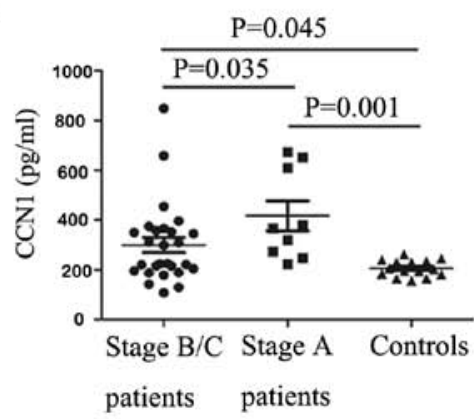

B

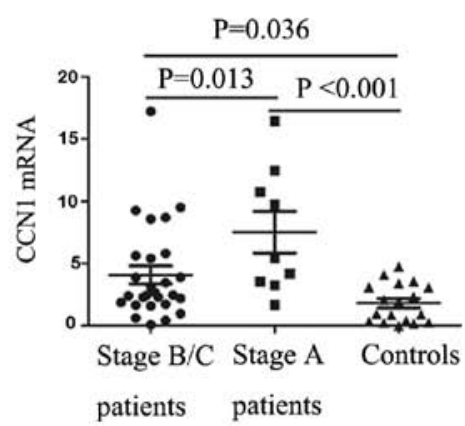

C
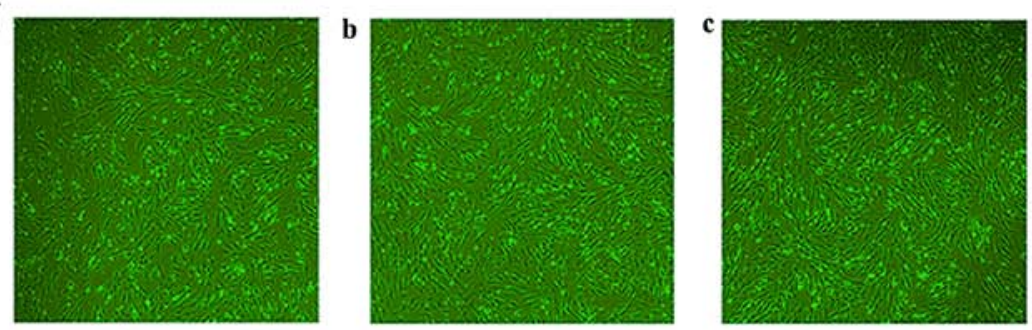

D
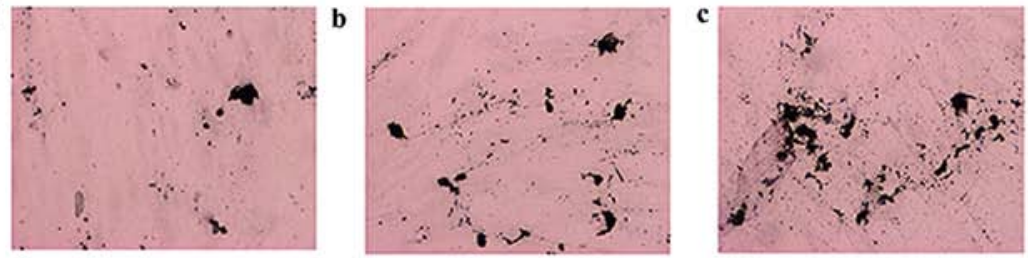

$\mathbf{E}$
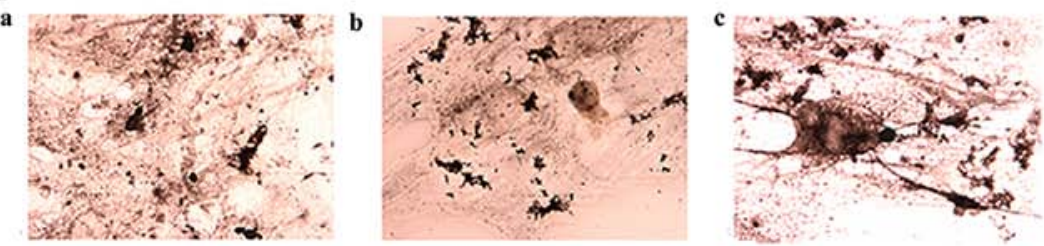

$\mathbf{F}$

G
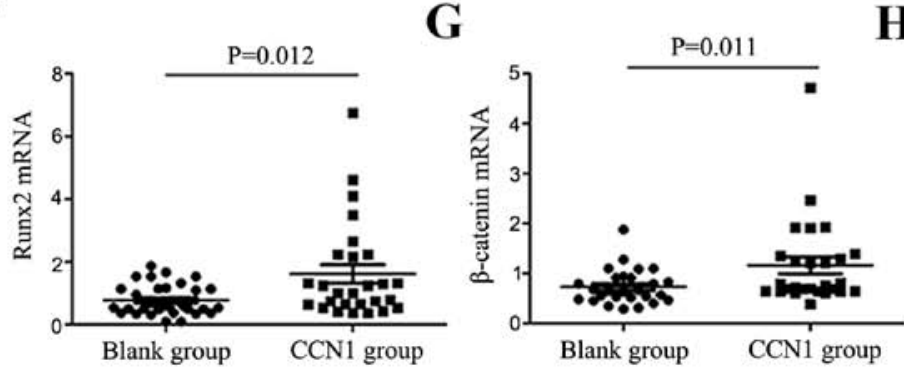

H

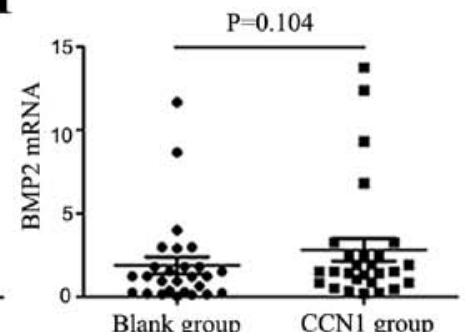

Figure 1. The level of CCN1 in newly diagnosed patients and the effect of CCN1 on OBs in vitro. (A) The level of CCN1 in BM supernatant in patients in stage $\mathrm{A}$ and $\mathrm{B} / \mathrm{C}$ were both significantly higher than the normal controls. (B) The mRNA level of CYR61 in patients in different stages were significantly higher than the normal controls. (C) The quantity of OBs increased in $10 \mathrm{ng} / \mathrm{ml} \mathrm{CCN1}$ (b) and $30 \mathrm{ng} / \mathrm{ml} \mathrm{CCN1}$ (c) than the blank (a). (D) The amount of mineralized nodules cultured with $30 \mathrm{ng} / \mathrm{CCN} 1$ (c) was also significantly increased compared to the blank group (a), while there was no significant difference in $10 \mathrm{ng} / 1$ CCN1 group (b). (E) ALP staining became strongly positive after CCN1 stimulation [10 ng/ml (b) and $30 \mathrm{ng} / \mathrm{ml}$ (c)] compared with control (a). Runx2 (F) and $\beta$-catenin (G) mRNA levels were significantly increased after $30 \mathrm{ng} / \mathrm{ml} \mathrm{CCN1}$ stimulation. While BMP2 level had no significant change (H).

$416.90 \pm 179.78$ and $299.48 \pm 160.65 \mathrm{pg} / \mathrm{ml}$, which were both significantly higher than normal controls $[202.12 \pm 41.53 \mathrm{pg} / \mathrm{ml}$ $(\mathrm{P}=0.001$ and 0.045)] (Fig. 1A). Also, the level of CCN1 in stage A was significantly higher than stage $\mathrm{B} / \mathrm{C}(\mathrm{P}=0.035)$, indicating that $\mathrm{CCN} 1$ may have a promoting role in bone remodeling.
Previous research has shown that CYR61 was not expressed in normal plasma cells, MM cells, osteoclasts, but highly expressed in MSCs (10). We further detected the expression of CYR61 in OBs by real-time PCR. The median CYR61 mRNA levels in the patients in stage $\mathrm{A}$ and stage $\mathrm{B} / \mathrm{C}$ were 5.45 (0.08-17.23) and 2.46 (1.68-16.48), both significantly increased 
A

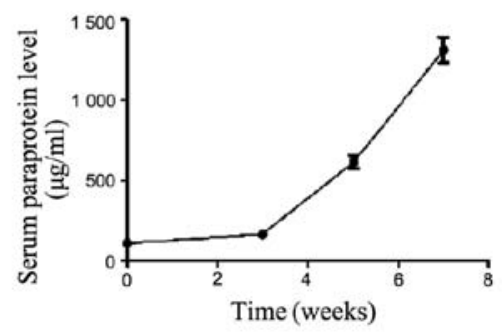

B

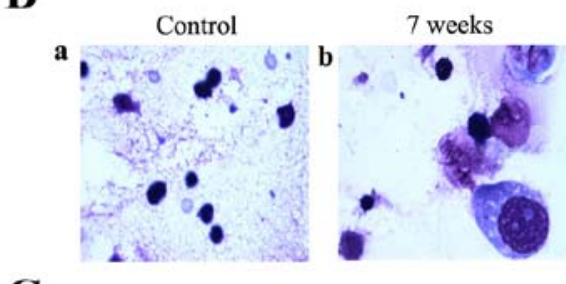

C

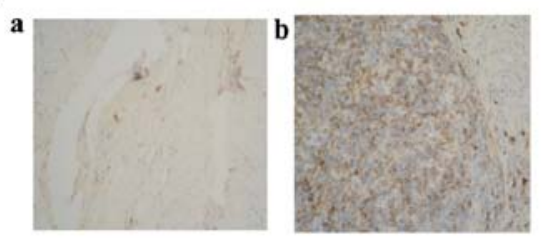

D

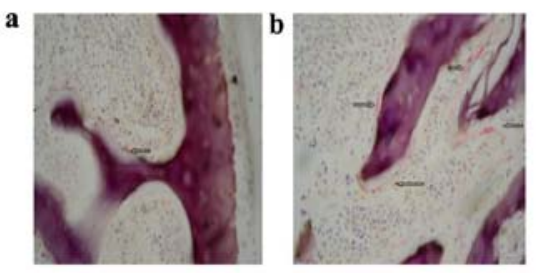

E
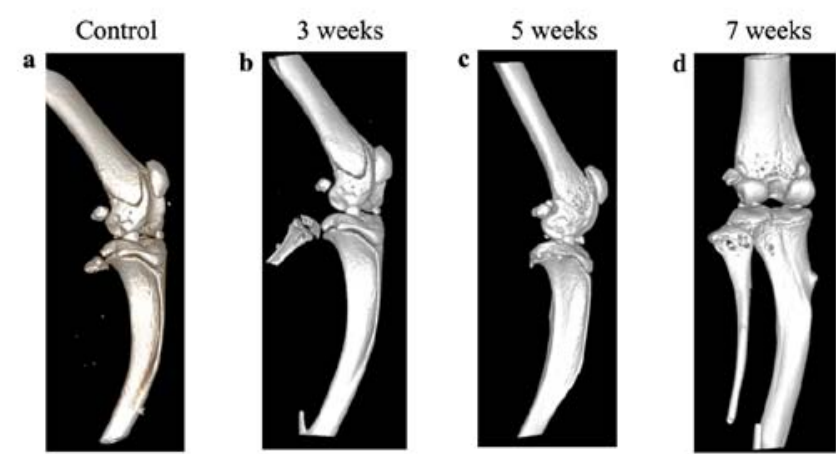

F
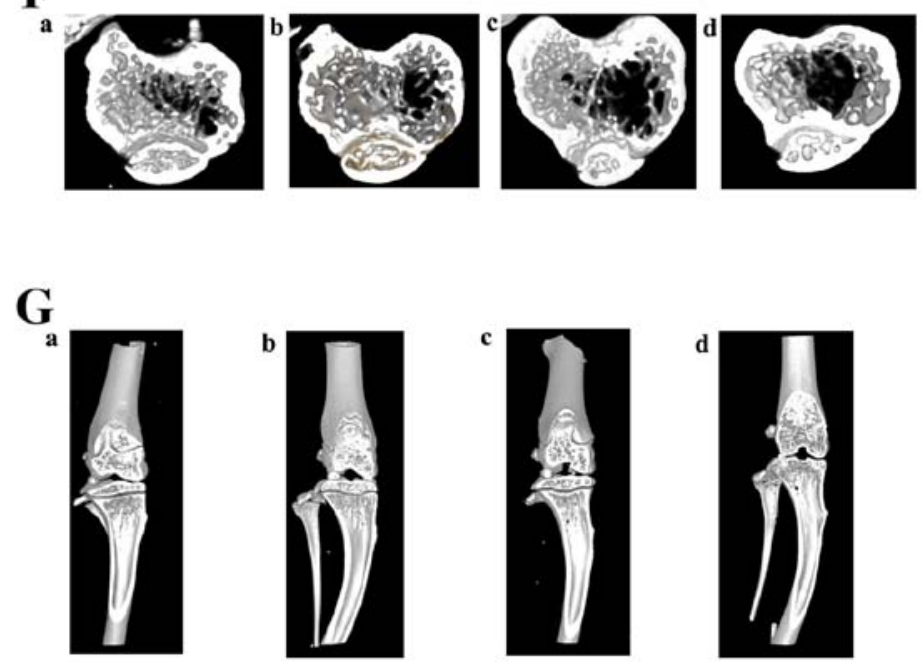

Figure 2. Myeloma bone disease mouse model. (A) Myeloma cells (RPMI-8226) were injected directly into the marrow space of right tibiae of NOD/SCIDcc null mice, PBS injected into mice as controls. Serum monoclonal Ig level of mice was detected by ELISA at 0, 3, 5 and 7 weeks after the myeloma cell injection. (B) Myeloma cells in BM were observed by H\&E staining in the mouse model at 7 weeks after injection (b) compared with controls (a) (x400). (C) CD138 staining by immunohistochemistry positive in the mouse model (b), while negative in controls (a) at 7 weeks after injection (x400). (D) TRAP staining was positive as indicated by the arrows in mouse model (b) while negative in controls (a) 7 weeks later (x400). Bone damage by microCT were observed in the mouse model from lateral (E-b-d), coronal (F-b-d) and sagittal scan (G-b-d) at 3, 5 and 7 weeks after the myeloma cell injection, compared with the controls (E-a, F-a and G-a).

compared with normal controls $(1.47,0.01-4.76)(\mathrm{P}<0.001$ and $\mathrm{P}=0.036)$. Similarly, the level of stage A was significantly higher than stage $\mathrm{B} / \mathrm{C}(\mathrm{P}=0.013)$ (Fig. 1B).

CCN1 promotes proliferation and mineralization of $O B s$ in vitro. The $\mathrm{OBs}$ from the patients in stage $\mathrm{B} / \mathrm{C}$ were incubated without or with CCN1 (10 and $30 \mathrm{ng} / \mathrm{l})$ for $24 \mathrm{~h}$ in vitro (16) and the quantity and function of OBs were subsequently observed. Matrix formation and mineralization were also investigated by histochemistry. ALP and Von Kossa staining positively identified the OBs. The quantity and function of OBs both continuously increased with increasing $\mathrm{CCN} 1$ concentration (Fig. 1C-E). The OB quantity cultured with different CCN1 concentrations (10 and $30 \mathrm{ng} / \mathrm{l}$ ) were $3.01 \pm 0.49 \times 10^{5} / \mathrm{ml}$ and $3.39 \pm 1.21 \times 10^{5} / \mathrm{ml}$, while there was significant difference between the blank group and $30 \mathrm{ng} / \mathrm{l} \mathrm{CCN1}$ group $(\mathrm{P}=0.046)$. The amount of mineralized nodules cultured with $30 \mathrm{ng} / \mathrm{l}$ CCN1 $(14.33 \pm 5.72 / \mathrm{HPF})$ was also significantly increased compared to the blank group $(9.11 \pm 0.97 / \mathrm{HPF})(\mathrm{P}=0.048)$,
Table III. Quantity and function of OBs cultured with different concentration of CCN1.

\begin{tabular}{lcc}
\hline & $\begin{array}{c}\text { No. of cells } \\
\left(10^{5} / \mathrm{ml}\right)\end{array}$ & $\begin{array}{c}\text { No. of mineralized } \\
\text { nodules }(/ \mathrm{HPF})\end{array}$ \\
\hline Blank & $2.72 \pm 0.24$ & $9.11 \pm 0.97$ \\
CCN1 (10 ng/l) & $3.01 \pm 0.49$ & $11.82 \pm 3.76$ \\
CCN1 (30 ng/l) & $3.39 \pm 1.21^{\mathrm{a}}$ & $14.33 \pm 5.72^{\mathrm{a}}$ \\
\hline
\end{tabular}

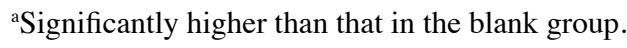

while there was no significant difference in $10 \mathrm{ng} / \mathrm{l} \mathrm{CCN1}$ group (11.82 $\pm 3.76 / \mathrm{HPF})$ (Table III). According to these results, we found that suitable concentration of CCN1 stimulating the OBs was $30 \mathrm{ng} / \mathrm{l}$. Therefore, we detected the Runx2, $\beta$-catenin and BMP2 by real-time PCR in $30 \mathrm{ng} / 1 \mathrm{CCN} 1$ incubation, not 10 ng/l CCN1. 
Table IV. The three-dimensional (3D) parameters in myeloma bone disease mouse model.

\begin{tabular}{lcccccc}
\hline & $\begin{array}{c}\text { Total bone volume/ } \\
\text { total volume }\end{array}$ & $\begin{array}{c}\text { Bone surface area/ } \\
\text { bone volume }\end{array}$ & $\begin{array}{c}\text { Trabecular } \\
\text { thickness }\end{array}$ & $\begin{array}{c}\text { Trabecular } \\
\text { number }\end{array}$ & $\begin{array}{c}\text { Trabecular } \\
\text { spacing }\end{array}$ & $\begin{array}{c}\text { Trabecular bone } \\
\text { volume }\left(\mathrm{mm}^{3}\right)\end{array}$ \\
\hline Controls & $0.5224 \pm 0.06294$ & $24.5472 \pm 7.14071$ & $0.0879 \pm 0.02992$ & $5.4937 \pm 0.6331$ & $0.0962 \pm 0.00779$ & $1.533-0.20391$ \\
3 weeks & $0.4959 \pm 0.01369$ & $23.8545 \pm 2.32456$ & $0.0844 \pm 0.00797$ & $5.9045 \pm 0.41117$ & $0.0855 \pm 0.00359$ & $1.3563 \pm 0.0498$ \\
5 weeks & $0.3650 \pm 0.06294^{\text {a }}$ & $28.1016 \pm 1.16317$ & $0.0713 \pm 0.00301$ & $6.4713 \pm 0.27484$ & $0.0835 \pm 0.00603$ & $1.1042 \pm 0.07738^{\text {a }}$ \\
7 weeks & $0.3218 \pm 0.06155^{\text {b }}$ & $33.4926 \pm 8.32048$ & $0.0620 \pm 0.01372$ & $5.799 \pm 0.618$ & $0.1118 \pm 0.03037$ & $0.7912 \pm 0.12501^{\text {b }}$
\end{tabular}

${ }^{\mathrm{a}}$ Compared with controls, $\mathrm{P}=0.041$ (5 weeks), $\mathrm{P}=0.027$ (5 weeks). ${ }^{\mathrm{b}}$ Compared with controls, $\mathrm{P}=0.017$ (7 weeks), $\mathrm{P}=0.004$ (7 weeks).

Table V. The three-dimensional (3D) parameters in different groups.

\begin{tabular}{|c|c|c|c|c|c|c|}
\hline & $\begin{array}{l}\text { Total bone volume/ } \\
\text { total volume }\end{array}$ & $\begin{array}{l}\text { Bone surface area/ } \\
\text { bone volume }\end{array}$ & $\begin{array}{l}\text { Trabecular } \\
\text { thickness }\end{array}$ & $\begin{array}{l}\text { Trabecular } \\
\text { number }\end{array}$ & $\begin{array}{l}\text { Trabecular } \\
\text { spacing }\end{array}$ & $\begin{array}{l}\text { Trabecular bone } \\
\text { volume }\left(\mathrm{mm}^{3}\right)\end{array}$ \\
\hline Controls & $0.2759 \pm 0.10325$ & $43.1139 \pm 12.52269$ & $0.0492 \pm 0.0148$ & $5.5365 \pm 0.42373$ & $0.1321 \pm 0.02678$ & $0.7219 \pm 0.122$ \\
\hline $\begin{array}{l}\text { Zoledronic } \\
\text { acid }\end{array}$ & $0.4848 \pm 0.030^{\mathrm{a}}$ & $26.9035 \pm 1.582$ & $0.0745 \pm 0.004$ & $6.5056 \pm 0.014$ & $0.0792 \pm 0.005$ & $1.2839 \pm 0.077^{\mathrm{a}}$ \\
\hline $\begin{array}{l}\text { CCN1 over- } \\
\text { expression }\end{array}$ & $0.4541 \pm 0.03383^{\mathrm{b}}$ & $25.5417 \pm 1.19068$ & $0.0784 \pm 0.00367$ & $5.4492 \pm 0.36592$ & $0.0921 \pm 0.0078$ & $1.7539 \pm 0.16949^{\mathrm{b}, \mathrm{c}}$ \\
\hline
\end{tabular}

${ }^{\mathrm{a}}$ Compared with controls, $\mathrm{P}=0.014, \mathrm{P}=0.003$. ${ }^{\mathrm{b}} \mathrm{Compared}$ with controls, $\mathrm{P}=0.031 ; \mathrm{P}=0.001{ }^{\mathrm{c}}$ Compared with zoledronic acid, $\mathrm{P}=0.012$.

Runx 2 and $\beta$-catenin upregulation in OBs after CCN1 stimulation. The mRNA expressions of Runx $2, \beta$-catenin and BMP2 were analyzed to observe $\mathrm{OB}$ differentiation. These expressions were critical transcription factors of early OB differentiation (22). The median mRNA of Runx 2 in CCN1 group (30 ng/l) was 0.9965 (range, 0.3751-9.7473), which was significantly higher than that in the blank group (0.5421, 0.0938-1.8725) $(\mathrm{P}=0.012)$. The mRNA of $\beta$-catenin had a similar result. The median mRNA of $\beta$-catenin after CCN1 stimulating increased significantly from $0.6538(0.2836-1.8751)$ to $0.7540(0.3893-$ 4.7142) $(\mathrm{P}=0.011)$. However, the mRNA of BMP2 had no significant difference before and after CCN1 stimulation. The median mRNA of BMP2 in the blank and CCN1 group were $1.2414(0.0488-1.167)$ and $1.5390(0.2001-1.3756)$ (Fig. 1F-H).

Bone disease of MM animal model. In order to evaluate the myeloma animal model, we investigated the serum human monoclonal Ig $\lambda$ level by ELISA at 3, 5 and 7 weeks after myeloma cells injection. Compared with 3 weeks, there was a corresponding increase in $\operatorname{Ig} \lambda$ level. The serum human $\operatorname{Ig} \lambda$ level increased from 164.6 to 611.93 (5 weeks) and $1308.9 \mu \mathrm{g} / \mathrm{ml}$ (7 weeks) (Fig. 2A).

Myeloma cells in mouse bone marrow were observed by H\&E staining and immunohistochemistry (CD138) at 7 weeks. The results showed myeloma cells in tibiae (Fig. 2B) by morphology and positive CD138 expression (Fig. 2C), which comfirmed that human myeloma cells were injected directly into the bone marrow of the model mice.

Furthermore, we observed bone disease by microCT at 3 , 5 and 7 weeks and TRAP staining in BM at 7 weeks. TRAP staining, which revealed increased number of osteoclasts in tibiae, was stronger in the mouse model (Fig. 2D-b) compared with controls (Fig. 2D-a). We observed the lateral, coronal and sagittal scan of mouse tibiae and analyzed several three-dimensional (3D) parameters to assess the bone disease. The results showed that bone damage existed in images from 5 weeks and became worse at 7 weeks after injection (Fig. 2E-G). Table IV shows the three-dimensional (3D) parameters. The total bone volume/total volume at 5 and 7 weeks significantly increased compared with controls $(\mathrm{P}=0.041$ and 0.017$)$. Also, trabecular bone volume at 5 and 7 weeks were also significantly higher than controls $(\mathrm{P}=0.027$ and 0.004$)$. While other parameters had no significant changes.

CCN1 effect on bone remodeling in MBD mouse model. To evaluate the efficacy of CCN1 on bone remodeling, we established a CCN1 overexpression model of MM, in which transduced RPMI-8226/CYR61 cells were injected directly into the marrow tibial cavity of mice. Moreover, we used RPMI-8226/EV as negative control and zoledronic acid as positive control. Compared with RPMI-8226/EV, the transduced RPMI-8226/CYR61 cells expressed CCN1 by RT-PCR, ELISA and western blotting, but the proliferation of the cells was not affected by transduction (Fig. 3).

Radiographic analysis of the bones showed that bones exhibited decreased resorption in CCN1 overexpression group and zoledronic acid group, while severe resorption in negative control group (Fig. 4A-C). TRAP staining was negative in $\mathrm{CCN} 1$ overexpression group and zoledronic acid group, compared with control (Fig. 4D). Table V shows that total 
A

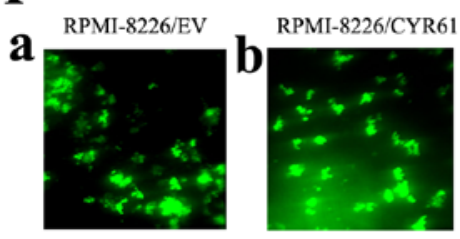

D

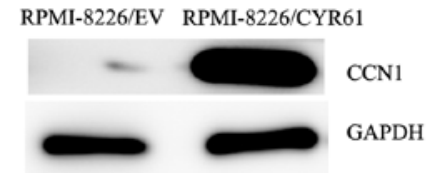

B

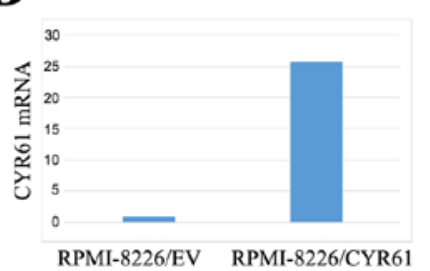

$\mathbf{E}$

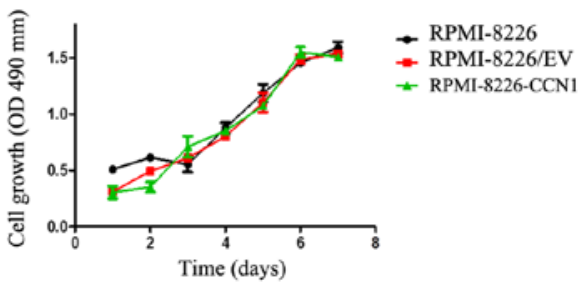

C

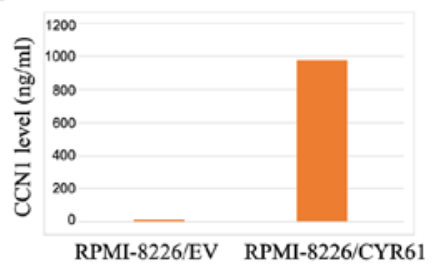

Figure 3. The transduced RPMI-8226/CYR61 cells overexpressed CCN1, while their growth was not affected. (A) RPMI-8226 cells were transduced with lentivirus expressing either CYR61-GFP or GFP only (empty vector, EV). (B) CYR61 mRNA expressed positively in RPMI-8226/CYR61 cells. (C) CCN1 levels in the conditioned medium of RPMI-8226/CYR61 or RPMI-8226/EV transduced cells were measured by ELISA. (D) Transduced RPMI-8226/CYR61 cells overexpressed CCN1 compared to RPMI-8226/EV cells by western blotting. (E) Non-tranduced RPMI-8226 and transduced RPMI-8226/CYR61 or RPMI-8226/EV cells were cultured for 7 days and the proliferation of cells was detected by CCK- 8 .

A
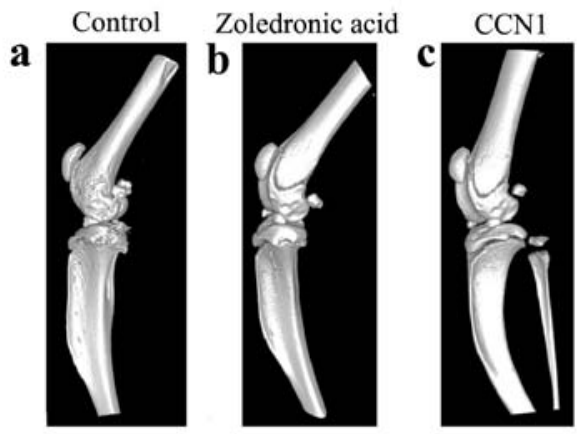

B
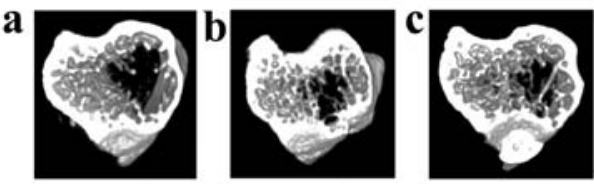

C
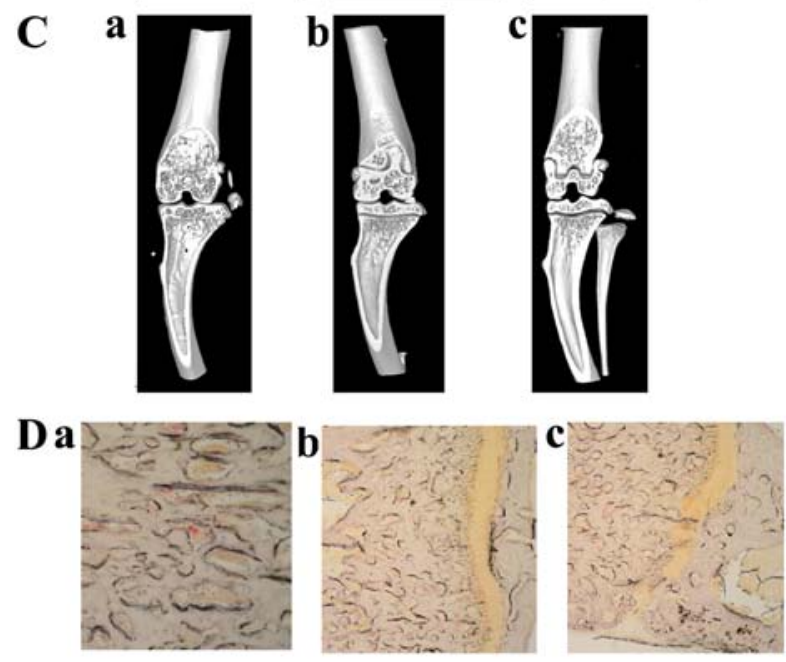

Figure 4. The effect of CCN1 in MBD mouse model. The mice were divided into three groups: control, zoledronic acid group and CCN1 overexpression group. MicroCT showed that the bones exhibited decreased resorption in CCN1 overexpression group (A-c, B-c and C-c) and zoledronic acid group (A-b, B-b and C-b), while severe resorption in control group (A-a, B-a and $\mathrm{C}$-a). TRAP staining was negative in $\mathrm{CCN} 1$ overexpression group (D-c) and zoledronic acid group (D-b), compared with control (D-a) (x200). bone volume/total volume and trabecular bone volume in both CCN1 overexpression group and zoledronic acid group were significantly increased compared with controls. Furthermore, trabecular bone volume in CCN1 overexpression group was $(1.7539 \pm 0.16949)$, which was significantly higher than that in zoledronic acid group $(1.2839 \pm 0.077)(\mathrm{P}=0.012)$.

\section{Disscusion}

MM is a malignancy of terminally differentiated plasma cells and produces bone disease in $80 \%$ of patients $(23,24)$. How to cure the bone disease of MM patients is still a challenge for the researchers and physicians. Recent studies indicated many cytokines in BM microenvironment play a role in the pathogenesis of malignant diseases $(25,26)$. CYR61, which encodes the secreted protein CCN1, plays an important role on bone remodeling in physiological and pathological processes. We found that CCN1 levels in BM supernatant and OBs both increased in the newly diagnosed MM patients, especially in the patients without bone disease, indicating CCN1 maybe play a protective role in MBD.

In order to observe the effect of CCN1, we used two concentrations of $\mathrm{CCN} 1$ (10 and $30 \mathrm{ng} / \mathrm{ml})$ to stimulate OBs, the results showed that the quantity and mineralization ability of OBs increased significantly at $30 \mathrm{ng} / \mathrm{ml}$ concentration. Furthermore, we detected the mRNA levels of Runx2, $\beta$-catenin and BMP2 to evaluate the differentiation of OBs. As known, the canonical $\mathrm{Wnt} / \beta$-catenin pathway is an important pathway regulating the differentiation of OBs $(27,28)$. BMP2 and Runx2 also take part in the osteogenetic process. Some studies have identified that Runx2 is one of major target gene of BMP2, which is a key regulator of osteoblast differentiation and bone development (29-33). In our study, the mRNA levels of $\beta$-catenin and Runx 2 increased after the CCN1 stimulation, while the BMP2 had no significant change. Gaur et al (34) suggested that canonical Wnt signaling promoted osteogenesis by directly stimulating Runx 2 gene expression. Therefore, the 
CCN1 stimulated the growth and mineralization of OBs in MBD patients mainly via Wnt signaling pathway.

It is well known that MM is a heterogeneous malignant disease, featured by various subtypes and different outcomes (35). It also determines that the characteristics of myeloma cells in different patients are diverse. Because myeloma cells react with OBs in different ways $(36,37)$, the OBs in different patients maybe exhibit diverse performances. Our results in real-time PCR are presented as median, which perhaps support this hypothesis.

In order to investigate the role of $\mathrm{CCN} 1$ in bone remodeling in vivo, we tried to build a mouse model of MBD. There are several kinds of MBD models, including 5T2MM model (38), MOPC35.BM model (39) and transgenic mouse models (Myc/Bcl-XL mice) (40). However, these models are made by injection or transgene of mouse myeloma cells, which can not recapitulate the human condition of $\mathrm{BM}$ microenvironment and bone disease. Considering the availability, technology and cost, we injected the human myeloma cells (RPMI-8226) to mice, similar to Labrinidis et al (19). We detected the myeloma cells in mouse bone marrow by H\&E staining and immunochemistry staining (CD138), which indicated the human myeloma cells grew in the mice. Furthermore, we observed the bone lesions by microCT and TRAP staining to identify the bone disease.

In this mouse model, overexpressed CCN1 in engrafted RPMI-8226 cells resulted in reduced bone disease, suggesting that CCN1 plays a positive effect on progression of bone lesions. Our results also indicated that the effect of CCN1 may be better than zoledronic acid, a first line treatment of MBD (41).

In conclusion, $\mathrm{CCN} 1$ is overexpressed in $\mathrm{BM}$ supernatant and $\mathrm{OB}$ in newly diagnosed myeloma patients, especially in the patients without bone disease, which could stimulate the proliferation and differentiation of OBs in vitro and contribute to bone remodeling in vivo. However, we still need to deeply investigate the signaling pathway of $\mathrm{CCN} 1$ on $\mathrm{OBs}$ to explore its mechanism.

\section{Acknowledgements}

This study was supported by the National Natural Science Foundation of China (grant nos. 81570106 and 81400088, 81600093), the anticancer major special project of Tianjin (grant no. 12ZCDZSY18000), the Tianjin Municipal Natural Science Foundation (grant nos. 14JCYBJC25400 and 15JCYBJC24300), Tianjin Health and Family Planning Commision (grant no. 15KG150) and the Science and Technology Foundation of Tianjin Municipal Health Bureau (grant nos. 2011kz115 and 2014KZ120).

\section{References}

1. Anderson KC: Oncogenomics to target myeloma in the bone marrow microenvironment. Clin Cancer Res 17: 1225-1233, 2011.

2. Yaccoby S: Osteoblastogenesis and tumor growth in myeloma. Leuk Lymphoma 51: 213-220, 2010.

3. Vallet S, Smith MR and Raje N: Novel bone-targeted strategies in oncology. Clin Cancer Res 16: 4084-4093, 2010.

4. Boyce BF and Xing L: The RANKL/RANK/OPG pathway. Curr Osteoporos Rep 5: 98-104, 2007.
5. Vallet S, Pozzi S, Patel K, Vaghela N, Fulciniti MT, Veiby P Hideshima T, Santo L, Cirstea D, Scadden DT, et al: A novel role for CCL3 (MIP-1 $\alpha$ ) in myeloma-induced bone disease via osteocalcin downregulation and inhibition of osteoblast function. Leukemia 25: 1174-1181, 2011.

6. Fu R, Liu H, Zhao S, Wang Y, Li L, Gao S, Ruan E, Wang G, Wang H, Song J, et al: Osteoblast inhibition by chemokine cytokine ligand 3 in myeloma-induced bone disease. Cancer Cell Int 12: 132, 2014

7. Scullen T, Santo L, Vallet S, Fulciniti M, Eda H, Cirstea D, Patel K, Nemani N, Yee A, Mahindra A, et al: Lenalidomide in combination with an activin A-neutralizing antibody: Preclinical rationale for a novel anti-myeloma strategy. Leukemia 27: 1715-1721, 2013.

8. Kristensen IB, Christensen JH,Lyng MB, Møller MB, Pedersen L, Rasmussen LM, Ditzel HJ and Abildgaard N: Hepatocyte growth factor pathway upregulation in the bone marrow microenvironment in multiple myeloma is associated with lytic bone disease. Br J Haematol 161: 373-382, 2013

9. Hiasa M, Teramachi J, Oda A, Amachi R, Harada T, Nakamura S, Miki H, Fujii S, Kagawa K, Watanabe K, et al: Pim-2 kinase is an important target of treatment for tumor progression and bone loss in myeloma. Leukemia 29: 207-217, 2015.

10. Johnson SK, Stewart JP, Bam R, Qu P, Barlogie B, van Rhee F, Shaughnessy JD Jr, Epstein J and Yaccoby S: CYR61/CCN1 overexpression in the myeloma microenvironment is associated with superior survival and reduced bone disease. Blood 124: 2051-2060, 2014

11. Perbal B: CCN proteins: Multifunctional signalling regulators. Lancet 363: 62-64, 2004.

12. Kireeva ML, Mo FE, Yang GP and Lau LF: Cyr61, a product of a growth factor-inducible immediate-early gene, promotes cell proliferation, migration, and adhesion. Mol Cell Biol 16: 1326-1334, 1996.

13. Clines GA, Mohammad KS, Bao Y, Stephens OW, Suva LJ, Shaughnessy JD Jr, Fox JW, Chirgwin JM and Guise TA: Dickkopf homolog 1 mediates endothelin-1-stimulated new bone formation. Mol Endocrinol 21: 486-498, 2007.

14. Si W, Kang Q, Luu HH, Park JK, Luo Q, Song WX, Jiang W, Luo X, Li X, Yin H, et al: CCN1/Cyr61 is regulated by the canonical Wnt signal and plays an important role in Wnt3Ainduced osteoblast differentiation of mesenchymal stem cells. Mol Cell Biol 26: 2955-2964, 2006.

15. Su JL, Chiou J, Tang CH, Zhao M, Tsai CH, Chen PS, Chang YW, Chien MH, Peng CY, Hsiao M, et al: CYR61 regulates BMP-2dependent osteoblast differentiation through alpha $\mathrm{v}$ beta 3 integrin/ILK/ERK pathway. J Biol Chem 285: 31325-31326, 2010.

16. Chen CY, Su CM, Huang YL, Tsai CH, Fuh LJ and Tang CH: $\mathrm{CCN} 1$ induces oncostatin $\mathrm{M}$ production in osteoblasts via integrin-dependent signal pathways. PLoS One 9: e106632, 2014.

17. Terpos E, de la Fuente J, Szydlo R, Hatjiharissi E, Viniou N, Meletis J, Yataganas X, Goldman JM and Rahemtulla A: Tartrate-resistant acid phosphatase isoform 5b: A novel serum marker for monitoring bone disease in multiple myeloma. Int J Cancer 106: 455-457, 2003.

18. Li X, Pennisi A and Yaccoby S: Role of decorin in the antimyeloma effects of osteoblasts. Blood 112: 159-168, 2008.

19. Labrinidis A, Diamond P, Martin S, Hay S, Liapis V, Zinonos I, Sims NA, Atkins GJ, Vincent C, Ponomarev V, et al: Apo2L/ TRAIL inhibits tumor growth and bone destruction in a murine model of multiple myeloma. Clin Cancer Res 15: 1998-2009, 2009.

20. Schwarzer R, Nickel N, Godau J, Willie BM, Duda GN, Schwarzer R, Cirovic B, Leutz A, Manz R, Bogen B, et al: Notch pathway inhibition controls myeloma bone disease in the murine MOPC315.BM model. Blood Cancer J 4: e217, 2014.

21. Kristensen IB, Christensen JH,Lyng MB, Møller MB, Pedersen L, Rasmussen LM, Ditzel HJ and Abildgaard N: Expression of osteoblast and osteoclast regulatory genes in the bone marrow microenvironment in multiple myeloma: Only up-regulation of Wnt inhibitors SFRP3 and DKK1 is associated with lytic bone disease. Leuk Lymphoma 55: 911-919, 2014.

22. Silvestris F, Cafforio P, De Matteo M, Calvani N, Frassanito MA and Dammacco F: Negative regulation of the osteoblast function in multiple myeloma through the repressor gene E4BP4 activated by malignant plasma cells. Clin Cancer Res 14: 6081-6091, 2008.

23. Kristinsson SY, Minter AR, Korde N, Tan E and Landgren O: Bone disease in multiple myeloma and precursor disease: Novel diagnostic approaches and implications on clinical management. Expert Rev Mol Diagn 11: 593-603, 2011. 
24. Giuliani N, Rizzoli V and Roodman GD: Multiple myeloma bone disease: Pathophysiology of osteoblast inhibition. Blood 108: 3992-3996, 2006.

25. Olechnowicz SW and Edwards CM: Contributions of the host microenvironment to cancer-induced bone disease. Cancer Res 74: 1625-1631, 2014.

26. Andrews SW, Kabrah S, May JE, Donaldson C and Morse HR: Multiple myeloma: The bone marrow microenvironment and its relation to treatment. Br J Biomed Sci 70: 110-120, 2013.

27. Glass DA II, Bialek P, Ahn JD, Starbuck M, Patel MS, Clevers H, Taketo MM, Long F, McMahon AP, Lang RA, et al: Canonical Wnt signaling in differentiated osteoblasts controls osteoclast differentiation. Dev Cell 8: 751-764, 2005.

28. Hill TP, Später D, Taketo MM, Birchmeier W and Hartmann C: Canonical Wnt/ $\beta$-catenin signaling prevents osteoblasts from differentiating into chondrocytes. Dev Cell 8: 727-738, 2005.

29. Nishio Y, Dong Y, Paris M, O'Keefe RJ, Schwarz EM and Drissi H: Runx2-mediated regulation of the zinc finger Osterix/ Sp7 gene. Gene 372: 62-70, 2006.

30. Bae JS, Gutierrez S, Narla R, Pratap J, Devados R, van Wijnen AJ, Stein JL, Stein GS, Lian JB and Javed A: Reconstitution of Runx2/Cbfa1-null cells identifies a requirement for BMP2 signaling through a Runx2 functional domain during osteoblast differentiation. J Cell Biochem 100: 434-449, 2007.

31. Maruyama Z, Yoshida CA, Furuichi T, Amizuka N, Ito M, Fukuyama R, Miyazaki T, Kitaura H, Nakamura K, Fujita T, et al: Runx 2 determines bone maturity and turnover rate in postnatal bone development and is involved in bone loss in estrogen deficiency. Dev Dyn 236: 1876-1890, 2007.

32. Jeon EJ, Lee KY, Choi NS, Lee MH, Kim HN, Jin YH, Ryoo HM, Choi JY, Yoshida M, Nishino N, et al: Bone morphogenetic protein-2 stimulates Runx2 acetylation. J Biol Chem 281: 16502-16511, 2006

33. Yang S, Wei D, Wang D, Phimphilai M, Krebsbach PH and Franceschi RT: In vitro and in vivo synergistic interactions between the Runx2/Cbfa1 transcription factor and bone morphogenetic protein-2 in stimulating osteoblast differentiation. J Bone Miner Res 18: 705-715, 2003.
34. Gaur T, Lengner CJ, Hovhannisyan H, Bhat RA, Bodine PV, Komm BS, Javed A, van Wijnen AJ, Stein JL, Stein GS, et al: Canonical WNT signaling promotes osteogenesis by directly stimulating Runx2 gene expression. J Biol Chem 280 33132-33140, 2005.

35. Szalat R and Munshi NC: Genomic heterogeneity in multiple myeloma. Curr Opin Genet Dev 30: 56-65, 2015.

36. Colucci S, Brunetti G, Oranger A, Mori G, Sardone F, Specchia G, Rinaldi E, Curci P, Liso V, Passeri G, et al: Myeloma cells suppress osteoblasts through sclerostin secretion. Blood Cancer J 1: e27, 2011.

37. Giuliani N, Colla S, Morandi F, Lazzaretti M, Sala R, Bonomini S, Grano M, Colucci S, Svaldi M and Rizzoli V: Myeloma cells block RUNX2/CBFA1 activity in human bone marrow osteoblast progenitors and inhibit osteoblast formation and differentiation. Blood 106: 2472-2483, 2005.

38. Vanderkerken K, De Raeve H, Goes E, Van Meirvenne S, Radl J, Van Riet I, Thielemans K and Van Camp B: Organ involvement and phenotypic adhesion profile of 5T2 and 5T33 myeloma cells in the C57BL/KaLwRij mouse. Br J Cancer 76: 451-460, 1997.

39. Hofgaard PO, Jodal HC, Bommert K, Huard B, Caers J, Carlsen H, Schwarzer R, Schünemann N, Jundt F, Lindeberg MM, et al: A novel mouse model for multiple myeloma (MOPC315.BM) that allows noninvasive spatiotemporal detection of osteolytic disease. PLoS One 7: e51892, 2012.

40. Cheung WC, Kim JS, Linden M, Peng L, Van Ness B, Polakiewicz RD and Janz S: Novel targeted deregulation of c-Myc cooperates with Bcl-X (L) to cause plasma cell neoplasms in mice. J Clin Invest 113: 1763-1773, 2004

41. Morgan GJ, Davies FE, Gregory WM, Cocks K, Bell SE, Szubert AJ, Navarro-Coy N, Drayson MT, Owen RG, Feyler S, et al; National Cancer Research Institute Haematological Oncology Clinical Study Group: First-line treatment with zoledronic acid as compared with clodronic acid in multiple myeloma (MRC Myeloma IX): A randomised controlled trial. Lancet 376: $1989-1999,2010$ 